\title{
Peripheral biomarkers revisited: Integrative profiling of peripheral samples for psychiatric research
}

\author{
Akiko Hayashi-Takagi ${ }^{1,2}$, Marquis P. Vawter ${ }^{3}$, and Kazuya Iwamoto ${ }^{2,4}$ \\ ${ }^{1}$ Laboratory of Structural Physiology, Center for Disease Biology and Integrative Medicine, Faculty of \\ Medicine, University of Tokyo, Bunkyo-ku, Tokyo 113-0033, Japan \\ ${ }^{2}$ PRESTO, Japan Science and Technology Agency, 4-1-8 Honcho, Kawaguchi, Saitama 332-0012, Japan \\ ${ }^{3}$ Department of Psychiatry and Human Behavior, Functional Genomics Laboratory, University of \\ California, Irvine, CA, 92697-4260, USA \\ ${ }^{4}$ Department of Molecular Psychiatry, Graduate School of Medicine, University of Tokyo, Bunkyo-ku, \\ Tokyo 113-8655, Japan \\ Address correspondence to Akiko Hayashi-Takagi \\ Laboratory of Structural Physiology, Center for Disease Biology and Integrative Medicine, Faculty of \\ Medicine, University of Tokyo, Bunkyo-ku, Tokyo 113-0033, Japan; E-mail: \\ hayashi888@m.u-tokyo.ac.jp, Tel.: +81-3-5841-1439, FAX: +81-3-5841-1442.
}

Number of figures/tables/supplemental information: 0/1/3

Number of words in abstract: 224

Number of words in text, excluding abstract, references, acknowledgments: 3982

Key Words: Biomarker, omics, peripheral sample, functional assay, diagnostic support, tailor-made therapy 
Hayashi-Takagi et al. 2

\section{Abstract}

Peripheral samples, such as blood and skin, have been used for decades in psychiatric research as surrogates for central nervous system samples. Although the validity of the data obtained from peripheral samples has been questioned, and other state-of-the-art techniques, such as human brain imaging, genomics, and induced pluripotent stem cells, seem to reduce the value of peripheral cells, accumulating evidence has suggested that revisiting peripheral samples is worthwhile. Here, we reevaluate the utility of peripheral samples and argue that establishing an understanding of the common signaling and biological processes in the brain and peripheral samples is required for the validity of such models. First, we present an overview of the available types of peripheral cells and describe their advantages and disadvantages. We then briefly summarize the main achievements of omics studies, including epigenome, transcriptome, proteome, and metabolome analyses, as well as the main findings of functional cellular assays, the results of which imply that alterations in neurotransmission, metabolism, the cell cycle, and the immune system may be partially responsible for the pathophysiology of major psychiatric disorders such as schizophrenia. Finally, we discuss the future utility of peripheral samples for the development of biomarkers and tailor-made therapies, such as multimodal assays that are used as a battery of disease and trait pathways, and that might be potent and complimentary tools for use in psychiatric research. 
Hayashi-Takagi et al. 3

\section{Introduction to the Use of Peripheral Samples for Psychiatric Research}

Despite extensive recent efforts, the pathogenesis of psychiatric disorders remains poorly understood, mainly because their pathophysiology is not immediately apparent in molecular or histopathological analyses of the human brain. Psychiatric disorders are diseases of the central nervous system (CNS), and, therefore, studies of patient-derived living brain cells provide the most pertinent information. Living brain biopsies from psychiatric patients are rare, and keeping noncancerous tissue alive is arduous because mature neurons do not readily divide. Thus, postmortem brains have been extensively used in brain studies, but these samples are subject to various artifacts that are related to medication, the cause of death, agonal state, and the postmortem interval $(1,2)$. It is therefore difficult to determine whether any observed changes are primary to the disease or are secondary compensatory effects from the protracted disease and its treatment. In addition, obtaining a sufficient number of brains, in ideal condition, is difficult. New techniques, such as those involving induced pluripotent stem cells (iPSCs), are undoubtedly powerful tools $(3,4)$, and the differentiation of iPSCs into different classes of brain cell provides an opportunity to study neurons from patients and therapeutic response profiles in vitro. Nonetheless, establishing the cells takes several weeks, and genetic instability and diversity exists, even among different clones from one individual. Thus, it is more feasible to obtain peripheral samples that can act as potential biomarkers of disease progression and therapeutic response at different time points.

Because psychiatric disorders, such as schizophrenia (SZ) and bipolar disorder (BPD), have genetic components (5), CNS alterations might be reflected in peripheral tissues. Indeed, microarray analyses 
Hayashi-Takagi et al. 4

have found numerous classes of genes that are expressed both in blood and the prefrontal cortex (PFC), including about half of the so-called SZ susceptibility genes (6). Intriguingly, about $50 \%$ of genetic variants have been shown to similarly affect transcript abundance in multiple tissues, including blood and brain (7). Furthermore, 22\% of the total transcriptome is expressed in both the cerebellum and peripheral blood mononuclear cells (PBMCs) with a high intrasubject correlation $(\gamma=0.98)$ at the genome-wide transcript level, which implies that gene expression in peripheral cells can serve as biomarkers for CNS disease (8). A recent expression quantitative trait loci analysis (eQTL) has also revealed that many cis-acting single-nucleotide polymorphisms (SNPs) are shared between blood and brain tissue (9).

However, there are multiple caveats to these preliminary observations, including that the blood and brain samples are not collected from the same subjects, there is little evidence on a global scale of differences in cases and controls for blood and brain expression, the evidence for single gene differences in both brain and blood is mixed and not corrected for genome-wide correlations, and the fold change is often discordant in blood-brain comparisons. Notwithstanding these limitations, a small number of genes have been shown to be identically altered in both the brain and blood of patients with autism (10). As for epigenetic variations, tissue-dependent epigenetic markers are now being investigated, and a list of candidate genes for peripheral biomarkers of diseases has been compiled $(11,12)$. Finally, one of the biggest advantages of peripheral sample cells is that they can be used for functional cellular analyses and the direct evaluation of dynamic cellular responses underlying various cellular events, which will be 
discussed in Section IV.

Despite the advantages of peripheral samples as surrogates for CNS samples, discouraging

results suggesting limited commonalities among different tissue types have been reported (13), and it is

crucial to determine which signaling pathways and biological processes are, and are not, conserved between CNS and peripheral samples. Peripheral samples should be used as surrogates only when common signaling pathways or biological processes are observed in the 2 types of samples. Table 1 shows the commonalities and/or differences between peripheral samples and the CNS. Peripheral signaling that is parallel with that in the CNS could unveil the pathophysiology of disease as well as future candidates for biomarkers.

In this review, we present an overview of the use of peripheral samples in classical techniques and for the development of disease models and biomarkers. A summary of all findings is beyond the scope of this paper, and we thus focus on the following 3 categories of samples: (1) freshly prepared primary cells, including red blood cells (RBCs), platelets, and lymphocytes; (2) primary cells with cell line-like features, including lymphoblastoid cell lines (LCLs) and fibroblasts; and (3) biofluids, including serum and plasma. Our review does not include olfactory epithelium cells despite their usefulness because they are considered neuronal cells and their sampling accessibility is relatively difficult, in contrast to peripheral samples.

\section{Available Types of Peripheral Samples}


Many primary cells tend to be highly differentiated, and they may lack many of the signaling pathways and biological processes that are present in the CNS. Even shared signaling pathways might function differently in different biological contexts. Thus, an empirical criterion for the use of primary cells is whether they share pathways or processes similar to those of the CNS cells of interest. Primary cells can be affected by presampling factors, such as health status, medication use, smoking, diet, and circadian rhythms. In contrast, cell line-like samples could potentially be free from environmental and state-related changes after a certain number of passages. The advantages of cell lines include the opportunity to obtain large amounts of molecular material and their ability to be cryopreserved in liquid nitrogen for later use. The characteristics of several types of freshly prepared cells, as well as primary cells, are briefly summarized in the following sections.

Peripheral Blood Cells. Peripheral blood is composed of fluidic (serum) and cellular components, which are collected by density-gradient centrifugation. Genomic DNA, RNA, and proteins that are extracted from cellular components are routinely used for genetic and biological studies. These cells and, particularly, lymphocytes are a major source of cytokines, and various hypotheses regarding the relationship between cytokine signaling and psychiatric disorders have been tested. For example, cytokines alter CNS functions that mediate behavioral responses, and the CNS, in turn, regulates lymphocyte metabolism $(14,15)$. Lymphocytes express a broad repertoire of receptors for cytokines, neuroendocrine hormones, and neuropeptides, including glucocorticoid, mineralocorticoid, 
Hayashi-Takagi et al. 7

brain-derived neurotrophic factor, dopamine (D2, D3, and D5), muscarinic and nicotinic acetylcholinergic, serotoninergic, GABAergic, cannabinoid, prolactin, and somatostatin receptors (16). A model of the complicated bidirectional communications between the CNS and non-CNS systems has been proposed (see Section IV).

Platelets are irregularly shaped anucleate cells that are easily isolated by centrifugation from platelet-rich plasma. They express a broad range of neurotransmitter receptors and transporters (17). Therefore, it is not surprising that platelets have been extensively used to examine the functional properties of receptors and transporter activities (see Neurotransmission). Some indexes of platelets have been correlated with those of the CNS (Table 1); for example, mitochondrial complex-I activity in platelets has been correlated with cerebral glucose utilization (18) and the severity of positive symptoms in patients with SZ (19). Neuroleptics have been found to induce parallel changes in the expression levels of serotonin and dopamine receptors in the CNS and in platelets (20). These findings support the use of platelets in the study of neurotransmitter receptor function in psychiatric disorders.

Mature human RBCs are also anucleate and thus cannot synthesize RNA. However, because all cell plasma membranes comprise a large number of common phospholipids, RBCs have frequently been used to study lipid metabolism (see Metabolism).

Serum/plasma has been frequently used for biomarker development (see Section V). Interestingly, cell-free circulating nucleic acids are present in serum, in which RNAs and microRNAs are very stable. Some RNAs and microRNAs are contained in small vesicles called exosomes, and they 
are secreted from distant cells and tissues, including the brain (21).

LCLs. Infection by the Epstein-Barr virus transforms human resting B cells into actively proliferating LCLs 1 month after infection (22). LCLs have several advantages over other types of cells. They proliferate rapidly and are nearly immortal. Thus, they can serve as an unlimited source of biomaterial and can be stored in liquid nitrogen. After reestablishment in culture (23), cells have been repeatedly used for multiple assays, including cellular functional assays (24). For instance, Sei et al. (25) have assessed the induction of cell migration by neuregulin1 (NRG1), which is a promising SZ susceptibility gene, in LCLs from patients with SZ, and they have found that NRG1-induced migration is significantly decreased compared to that of control individuals. Cell migration is highly influenced by NRG1 polymorphisms and epistatic interactions of $N R G 1$ with other SZ genes, clearly suggesting the benefit of assessing cellular events in combination with genetic variations for more than 1 SZ gene.

Fibroblasts. Skin fibroblast cultures can be easily established without any transformation process, and they can usually be maintained through approximately 20 passages. However, the age of the patients that can be examined is limited because fibroblasts from patients who are older than 50 years show shorter life spans in culture than cells from younger patients (26). The greatest advantage of fibroblasts may be their undifferentiated state, which is free from state-related changes such as those related to diet, hormones, and drugs. Because fibroblasts exhibit a broad range of genes that are 
involved in biological signaling, various processes in fibroblasts have been extensively studied, including genomic regulatory mechanisms, the cell cycle, cell adhesion, metabolism (glucose, lipid, and serine), neurotransmission, neurotrophin receptor-mediated signal transduction (adrenergic, cholinergic, and serotonergic), tyrosine transport capability, and cellular antioxidant defense (27-31).

\section{Omics Assays of Peripheral Samples}

\section{Omics approaches and effects of genotype}

Due to innovations in analytical techniques, omics approaches, in which all constituents are measured collectively at the same molecular level, have been extensively used. In this section, we review the results of epigenome, genome, transcriptome, proteome, and metabolome assays of peripheral samples, and a comprehensive list is shown in Supplementary Table S1. Omics data can be influenced by several factors, including genetic background, environmental factors, and stochastic events. Especially, epigenome and transcriptome information is known to be considerably influenced by the genotype of each individual. Many eQTL analyses have revealed that genomic variations within different ethnic groups can account for a substantial proportion of transcriptome variations. In the simple case, cis-located SNPs can affect transcription regulation by making or disrupting transcription factor binding sites. For the epigenome, SNPs that locate CpG sites disrupt cytosine DNA methylation, whereas those locating $\mathrm{DpG}$ or $\mathrm{CpH}$ create new methylation sites when SNPs form CpG sequences. Through the extensive comparison of the whole genome DNA methylation statuses of various tissues and cell lines, 
Hayashi-Takagi et al. 10

differentially methylated regions (DMRs) in the human genome have been reported to contain SNPs identified by various genome-wide association studies (32). Interestingly, DMRs in blood cells contain SNPs that are related to neurological and behavioral disorders, ensuring the importance of epigenome studies of peripheral blood samples. Numerous SNPs can affect proteome and metabolome information, which can be used to screen SNPs or mutations that have severe functional significance, including protein conformational changes or the accumulation or reduction of specific metabolites.

DNA methylation. Aberrant DNA methylation leads to a number of diseases, including cancer and mental retardation (33), and environmental insults have been reported to result in brain epigenetic alterations, which are associated with behavioral changes in animal models (34). Although epigenetic studies have usually been performed on postmortem brain tissue $(35,36)$, similar disease-associated DNA methylation changes at specific genomic regions have also been detected in peripheral samples $(37,38)$. This is a strong advantage of peripheral tissues compared to iPSCs because epigenetic markers are thought to be erased in reprogrammed cells. Global DNA hypomethylation has been repeatedly observed in peripheral leukocytes from patients with SZ, particularly patients with early-onset SZ (39) and males (40). Although the pathophysiological significance of DNA hypomethylation remains unclear, it is known to increase mutation rates and chromosomal instability (41), implicating disturbances in the mechanisms of genome integrity and maintenance in SZ. The epigenetic states of various SZ candidate genes have also been frequently examined in peripheral blood, saliva, and LCLs (36). It should be noted 
that the reported changes in DNA methylation levels are subtle (generally <5\%), and, thus, their pathophysiological role in psychiatric disorders is not clear. In addition, whether epigenetic changes are stable over time in peripheral tissues remains unclear. However, the number of reports of significant alterations in DNA methylation in peripheral cells has been increasing, and this research area provides new opportunities for studying psychiatric disorders.

Gene expression. Transcriptome analysis techniques, including DNA microarrays and next-generation sequencing, have been improving continuously. Array results have been generally difficult to compare and replicate because of platform and statistical differences $(42,43)$. However, data analyses that have focused on gene ontology have been used to compare studies. The early-stage studies of gene expression in peripheral samples have been reviewed elsewhere (44). Comprehensive array technologies have frequently been used to explore gene expression patterns in order to discriminate disease and disease subtypes from controls. For example, Tsuang et al. have suggested that 8 genes in peripheral cells are useful markers for the discrimination of patients with SZ and BPD from control subjects (45). The expression profile of 14 genes in peripheral blood cells has also been used to discriminate between patients with SZ and normal controls with an accuracy of 87.9\% (46). Although there have been many efforts to identify objective gene expression-based markers for psychiatric diagnoses, the identified genes rarely overlap across studies, and attempts to replicate previous findings in different cohorts have generally yielded disappointing results (47). 
Gene expression analyses within a well-characterized family or among discordant siblings may provide complementary information that would improve our understanding of risk and protective gene expression changes in individuals. Indeed, analyses of gene expression in blood samples from patients with SZ and their unaffected siblings, as well as unrelated control subjects, have identified expression changes that are shared between patients and their siblings and patient- or sibling-specific expression changes $(48,49)$. Similarly, Petryshen et al. have examined gene expression profiles in blood samples from discordant SZ siblings and identified genetic associations and concomitant alterations in the expression of several genes, including SMDF (a transcription variant of NRG1) and GABRB6 $(50,51)$. Another excellent example of the utilization of gene expression dynamics in peripheral cells is studies of circadian rhythms. Yang et al. have observed the altered expression of the clock-related genes $D E C 2$ and $D B P$ and a reduced amplitude of the rhythmic expression of BMAL1, REV-ERBalpha, and $D B P$ in fibroblasts of patients with BPD (52). Because cultured fibroblasts have a circadian clock that is comparable to that of the suprachiasmatic nucleus, clock signaling in fibroblasts may be a good model of the circadian disturbances that have been observed in patients with BPD.

Protein and metabolite levels. Molecular profiles that are obtained by proteome and metabolome analyses would be useful for developing biomarkers, and diagnostic purposes. For example, proteomic investigations of serum and RBCs from first-onset SZ patients, as well as those of postmortem brain and liver tissues in a different cohort, have revealed that ApoA1 downregulation was 
common to all 5 sample types (53). The downregulation of apolipoproteins, including ApoA1, in the serum of patients with SZ and BPD has also been reported in other proteomic studies $(54,55)$. Note, however, that the proteome and metabolome results are highly dependent on their techniques, because there are many different methods for sample preparation and analyte detection. Thus, there is much room for employing these approaches in analyzing peripheral tissues. The technical aspects and potential pitfalls have been the subject of excellent reviews elsewhere $(56,57)$.

\section{Functional Cellular Assays of Peripheral Samples}

Neurodevelopment and later plasticity involve continuous cellular responses to various stimuli, including neurotransmitters and neurotrophins, as well as to damaging stimuli. Therefore, direct investigations of dynamic cellular responses to stimuli would provide potential insights into psychiatric disorders. Supplementary Table S2 lists studies of the cellular dynamics of SZ individuals. Among the responses, we focus on cell signaling pathways that are common to the CNS and peripheral cells and that could be a powerful cellular model of functional assays in this section.

Neurotransmission. Human peripheral cells express several neurotransmitter receptors, including the NMDA- and AMPA-type glutamate receptor, and the associated second messenger molecules (16). Thus, peripheral cells have been used as a peripheral model of central synaptosomes. Indeed, platelets have been extensively used as models of central synaptosomes because they have been 
shown to accumulate glutamate and 5-HT like synaptosomal preparations $(28,58)$. Glutamate-stimulated

$\left[\mathrm{Ca}^{++}\right]_{\mathrm{i}}$ responses are reduced in the platelets of patients with SZ (59), which is similar to the findings of a recent report that suggested that relative NMDA receptor binding in the left hippocampus of medication-free SZ patients is significantly reduced compared to that in healthy subjects, as indicated by studies with a selective single-photon emission tomography NMDA receptor tracer (60). Considering that glutamatergic signaling dysregulation may contribute to SZ pathophysiology (61) and that some glutamate subunit genes have been shown to be positively associated with SZ (61), the use of platelets as a peripheral surrogate for glutamatergic transmission may be useful for functional studies.

Metabolism. A high prevalence of impaired glucose tolerance has been reproducibly reported in patients with SZ, even in drug-naive patients and first-degree relatives of affected individuals (62). Neuroimaging studies with positron emission tomography (PET) and magnetic resonance spectroscopy (MRS) have indicated metabolic alterations in several brain regions in subjects with SZ (63,64). A parallel transcriptomic, proteomic, and metabolomic approach to SZ brain tissue has suggested that half of the proteins that have been identified to be altered by proteomic analysis are associated with mitochondrial function and oxidative stress responses, and this result is mirrored by transcriptional and metabolic perturbations (65), thus implying altered cerebral energy metabolism and mitochondrial dysfunction in the pathophysiology of SZ. Mitochondrial complex-I activity in platelets has been shown to be correlated with PET cerebral glucose utilization (18) and psychiatric severity (19). 
Perturbed lipid metabolism has been suggested in SZ. Lipids make up over half of the brain's dry weight, and, thus, even small changes in key fatty acids can lead to a broad range of membrane dysfunctions, which may be particularly important during neurodevelopment because cell proliferation, neurite outgrowth, and synaptogenesis involve the dynamic synthesis and breakdown of phospholipids. In several conditions, including Down syndrome, lipid metabolism has been reported as abnormal in both neural and peripheral tissues (66), suggesting that membrane abnormalities are present in both neural and peripheral tissues in psychiatric conditions. Indeed, a variety of deficits in the metabolism of lipids in the RBCs and platelets of patients with SZ have been reported. Free fatty acids have been shown to be significantly decreased in the postmortem PFC of patients with SZ and the RBCs of living SZ patients (67-69). Six double-blind placebo-controlled studies of the use of eicosapentaenoic acid, which is a polyunsaturated fatty acid, for the treatment of SZ have been conducted, and 4 studies showed that eicosapentaenoic acid had clinical benefits in patients with SZ (70,71). Notably, clinical improvement is positively correlated with an increase in RBC lipid concentration (72), suggesting that RBC lipid concentration may serve as a biomarker of therapeutic efficacy. A significant correlation between RBC membrane fatty acids and in vivo brain phospholipid metabolite levels, as measured by multivoxel ${ }^{31} \mathrm{P}-\mathrm{MRS}$, has been consistently observed in the PFC of patients of SZ (68). However, the lack of correlations with other brain regions suggests that these results require further validation.

Cell Cycle and Apoptosis. Unbiased gene expression analyses have suggested that cell 
Hayashi-Takagi et al. 16

cycle-related pathways are significantly affected in postmortem SZ brains (73). At all stages of the cell cycle, if DNA has been irreversibly damaged, cells normally undergo apoptosis. It has been estimated that, depending on the region, $20-80 \%$ of all neurons that are formed in the CNS undergo apoptosis during development. Thus, apoptosis and cell cycle alterations may be underlying mechanisms of the neurodevelopment of SZ $(31,74,75)$. This possibility is supported by reports that $\mathrm{p} 53$, which is an apoptosis-related gene, is a susceptibility gene for SZ (76) and the reduced incidence rates of smoking-unrelated cancers in an epidemiological meta-analysis of SZ patients and their first-degree relatives (77). This reduced incidence rate suggests that a putative cell cycle disturbance might be observable in both the peripheral tissue and the brain. An excellent study of fibroblasts has suggested that the cell cycle is abnormal in individuals with SZ: fibroblasts from first-episode, drug-naive SZ patients take longer to establish initial growth and have prolonged doubling time compared to fibroblasts from control subjects (78). Intriguingly, the prolonged doubling time has been significantly associated with poorer premorbid social functioning during childhood (78). In addition, disrupted fibroblast responses to growth factors in first-episode, drug-naive psychotic patients have been observed (79).

Immune system. Many autoimmune diseases are more prevalent among patients with SZ, suggesting the involvement of immune-related dysfunction in SZ (80). Five genome-wide association studies of SZ have provided converging evidence for an association between SZ and the major 
histocompatibility complex (81). Many studies have examined the influence of various mitogens and neurotransmitters on cytokine secretion in lymphocytes, and a meta-analysis of 62 original studies that measured cytokines in blood samples from patients with SZ has verified a significant increase in the concentrations of IL-1RA, sIL-2R, and IL-6 (82,83). Histopathological and PET evidence for the pathological activation of microglia in SZ individuals is accumulating. Fate-mapping studies have shown that microglia and macrophages arise from a common primitive macrophage precursor, and gene expression profiling has shown a close relationship between bone marrow-derived macrophages and microglia in C57BL/6 mice (84). Because peripheral blood cells represent major cellular components of the immune system, they could be an appropriate template for the assessment of immune-related cellular dynamics.

\section{Disease Modeling and Biomarkers}

The diagnoses of psychiatric disorders depend solely on symptomatic information due to the lack of objective biomarkers. Thus, the establishment of practical state- and trait-dependent biomarkers in patient-derived peripheral samples is highly desirable. However, given that psychiatric disorders, including SZ, are highly heterogeneous and multifunctional, the discovery of a single biomarker with high specificity and sensitivity is unlikely. Of note, the first blood-based diagnostic aid for SZ, VeriPsych $^{\mathrm{TM}}$, was launched in 2010. This approach is based on a multiplex immunoassay format involving the simultaneous measurement of different protein and hormone biomarkers with implementation of an 
algorithm for a mathematical decision rule (85). Further refinement of the targeted molecules and the algorithm is now underway, and highly anticipated.

The other possible application of peripheral biomarkers is for clinical predictions, such as prognosis, relapse, drug response, and suicidal attempts. Because these predictions need to be easily and repeatedly measurable with a high degree of reproducibility, against reasonable costs, easy accessibility of the peripheral sample for the predictive biomarker would be highly appreciated for the clinical environment. Exploratory attempts have been extensively performed with peripheral samples (Supplementary Table S3). Interestingly, significant differences have been reported in blood-based molecular signatures at the last clinical visit before relapse, implying their use as possible predictors that help in clinical decisions to avoid relapse (86). Suicide is among the top 10 leading causes of death in individuals of all ages, and increased impulsivity is highly related to the transition from suicidal ideation to attempts. Even though impulsivity involves a heterogeneous repertoire of factors and potentially overlapping neurobiological substrates, they may be less genetically complex and more easily assessed than the psychiatric disorder itself. A summary of biological markers that link to future suicidal behavior has been made, but it is still challenging to find both promising and easily assessable peripheral predictors of suicide (Supplementary Table S3). In the future, it will be useful to examine multiple tests and risk factors, including peripheral markers, together with cerebrospinal fluid samples, brain imaging, and the patient history of attempted suicide in the prediction of suicide risk. Likewise, examining multiplex cellular responses to well-designed stimuli might provide predictions of other 
clinical variables, and these objective biomonitoring methods for affected individuals would enable

personalized therapeutic strategies with heuristic value.

\section{Acknowledgments}

This research was supported by grants from MEXT/JSPS KAKENHI (23689055 and 24116003 to A.

H-T; 24116009 and 24390279 to K.I) and a PREST program from the JST to A.H-T and K.I.

\section{Financial Disclosures}

The authors report no biomedical financial interests or potential conflicts of interest. 


\section{References}

1. Li JZ, Vawter MP, Walsh DM, Tomita H, Evans SJ, et al. (2004): Systematic changes in gene expression in postmortem human brains associated with tissue $\mathrm{pH}$ and terminal medical conditions. Hum Mol Genet 13: 609-616.

2. Hashimoto K, Sawa A \& Iyo M (2007): Increased levels of glutamate in brains from patients with mood disorders. Biol Psychiatry 62: 1310-1316.

3. Dolmetsch R \& Geschwind DH (2011): The human brain in a dish: the promise of iPSC-derived neurons. Cell 145: 831-834.

4. Brennand KJ, Simone A, Jou J, Gelboin-Burkhart C, Tran N, et al. (2011): Modelling schizophrenia using human induced pluripotent stem cells. Nature 473: 221-225.

5. Sullivan PF, Daly MJ \& O'Donovan M (2012): Genetic architectures of psychiatric disorders: the emerging picture and its implications. Nat Rev Genet 13: 537-551.

6. Sullivan PF, Fan C \& Perou CM (2006): Evaluating the comparability of gene expression in blood and brain. Am J Med Genet B Neuropsychiatr Genet 141B: 261-268.

7. Emilsson V, Thorleifsson G, Zhang B, Leonardson AS, Zink F, et al. (2008): Genetics of gene expression and its effect on disease. Nature 452: 423-428.

8. Rollins B, Martin MV, Morgan L \& Vawter MP (2010): Analysis of whole genome biomarker expression in blood and brain. Am J Med Genet B Neuropsychiatr Genet 153B: 919-936.

9. Hernandez DG, Nalls MA, Moore M, Chong S, Dillman A, et al. (2012): Integration of GWAS SNPs and tissue specific expression profiling reveal discrete eQTLs for human traits in blood and brain. Neurobiol Dis 47: 20-28.

10. Voineagu I (2012): Gene expression studies in autism: moving from the genome to the transcriptome and beyond. Neurobiol Dis 45: 69-75.

11. Davies MN, Volta M, Pidsley R, Lunnon K, Dixit A, et al. (2012): Functional annotation of the human brain methylome identifies tissue-specific epigenetic variation across brain and blood. Genome Biol 13: R43.

12. Horvath S, Zhang Y, Langfelder P, Kahn RS, Boks MP, et al. (2012): Aging effects on DNA methylation modules in human brain and blood tissue. Genome Biol 13: R97.

13. Glatt SJ, Everall IP, Kremen WS, Corbeil J, Sasik R, et al. (2005): Comparative gene expression analysis of blood and brain provides concurrent validation of SELENBP1 up-regulation in schizophrenia. Proc Natl Acad Sci U SA 102: 15533-15538.

14. Nawa H, Takahashi M \& Patterson PH (2000): Cytokine and growth factor involvement in schizophrenia--support for the developmental model. Mol Psychiatry 5: 594-603.

15. Boulanger LM (2009): Immune proteins in brain development and synaptic plasticity. Neuron 64: 93-109.

16. Gladkevich A, Kauffman HF \& Korf J (2004): Lymphocytes as a neural probe: potential for studying psychiatric disorders. Prog Neuropsychopharmacol Biol Psychiatry 28: 559-576. 
17. Morrell CN, Sun H, Ikeda M, Beique JC, Swaim AM, et al. (2008): Glutamate mediates platelet activation through the AMPA receptor. $J$ Exp Med 205: 575-584.

18. Ben-Shachar D, Bonne O, Chisin R, Klein E, Lester H, et al. (2007): Cerebral glucose utilization and platelet mitochondrial complex I activity in schizophrenia: A FDG-PET study. Prog Neuropsychopharmacol Biol Psychiatry 31: 807-813.

19. Dror N, Klein E, Karry R, Sheinkman A, Kirsh Z, et al. (2002): State-dependent alterations in mitochondrial complex I activity in platelets: a potential peripheral marker for schizophrenia. Mol Psychiatry 7: 995-1001.

20. Padin JF, Rodriguez MA, Dominguez E, Dopeso-Reyes IG, Buceta M, et al. (2006): Parallel regulation by olanzapine of the patterns of expression of 5-HT2A and D3 receptors in rat central nervous system and blood cells. Neuropharmacology 51: 923-932.

21. Thery C (2011): Exosomes: secreted vesicles and intercellular communications. F1000 Biol Rep $3: 15$.

22. Glade PR \& Beratis NG (1976): Long-term lymphoid cell lines in the study of human genetics. Prog Med Genet 1: 1-48.

23. Mello AS, Burin MG, Michellin K, Viapiana M, Giugliani R, et al. (2006): Epstein-Barr virus-induced transformation of $\mathrm{B}$ cells for the diagnosis of genetic metabolic disorders--enumerative conditions for cryopreservation. Cell Prolif 39: 29-36.

24. Hayashi A, Kasahara T, Kametani M, Toyota T, Yoshikawa T \& Kato T (2009): Aberrant endoplasmic reticulum stress response in lymphoblastoid cells from patients with bipolar disorder. Int $J$ Neuropsychopharmacol 12: 33-43.

25. Sei Y, Ren-Patterson R, Li Z, Tunbridge EM, Egan MF, et al. (2007): Neuregulin1-induced cell migration is impaired in schizophrenia: association with neuregulin1 and catechol-o-methyltransferase gene polymorphisms. Mol Psychiatry 12: 946-957.

26. Mahadik SP \& Mukherjee S (1996): Cultured skin fibroblasts as a cell model for investigating schizophrenia. J Psychiatr Res 30: 421-439.

27. Fekkes D, Pepplinkhuizen L \& Bruinvels J (1991): Changes in serine metabolism by a serum factor present in a group of episodic psychotic patients. Biol Psychiatry 30: 966-972.

28. Stahl SM (1985): Peripheral models for the study of neurotransmitter receptors in man. Psychopharmacol Bull 21: 663-671.

29. Chen Q \& Ames BN (1994): Senescence-like growth arrest induced by hydrogen peroxide in human diploid fibroblast F65 cells. Proc Natl Acad Sci U SA 91: 4130-4134.

30. Flyckt L, Venizelos N, Edman G, Bjerkenstedt L, Hagenfeldt L \& Wiesel FA (2001): Aberrant tyrosine transport across the cell membrane in patients with schizophrenia. Arch Gen Psychiatry 58: 953-958.

31. Catts VS, Catts SV, McGrath JJ, Feron F, McLean D, et al. (2006): Apoptosis and schizophrenia: a pilot study based on dermal fibroblast cell lines. Schizophr Res 84: 20-28.

32. Ziller MJ, Gu H, Muller F, Donaghey J, Tsai LT, et al. (2013): Charting a dynamic DNA 
methylation landscape of the human genome. Nature 500: 477-481.

33. Feinberg AP (2007): Phenotypic plasticity and the epigenetics of human disease. Nature 447: 433-440.

34. Tsankova N, Renthal W, Kumar A \& Nestler EJ (2007): Epigenetic regulation in psychiatric disorders. Nat Rev Neurosci 8: 355-367.

35. Petronis A (2010): Epigenetics as a unifying principle in the aetiology of complex traits and diseases. Nature 465: 721-727.

36. Nishioka M, Bundo M, Kasai K \& Iwamoto K (2012): DNA methylation in schizophrenia: progress and challenges of epigenetic studies. Genome Med 4: 96.

37. Dempster EL, Pidsley R, Schalkwyk LC, Owens S, Georgiades A, et al. (2011):

Disease-associated epigenetic changes in monozygotic twins discordant for schizophrenia and bipolar disorder. Hum Mol Genet 20: 4786-4796.

38. Kaminsky Z, Tochigi M, Jia P, Pal M, Mill J, et al. (2012): A multi-tissue analysis identifies HLA complex group 9 gene methylation differences in bipolar disorder. Mol Psychiatry 17: 728-740.

39. Melas PA, Rogdaki M, Osby U, Schalling M, Lavebratt C \& Ekstrom TJ (2012): Epigenetic aberrations in leukocytes of patients with schizophrenia: association of global DNA methylation with antipsychotic drug treatment and disease onset. FASEB J26: 2712-2718.

40. Shimabukuro M, Sasaki T, Imamura A, Tsujita T, Fuke C, et al. (2007): Global hypomethylation of peripheral leukocyte DNA in male patients with schizophrenia: a potential link between epigenetics and schizophrenia. J Psychiatr Res 41: 1042-1046.

41. Chen RZ, Pettersson U, Beard C, Jackson-Grusby L \& Jaenisch R (1998): DNA hypomethylation leads to elevated mutation rates. Nature 395: 89-93.

42. Wayland MT \& Bahn S (2006): Reproducibility of microarray studies: concordance of current analysis methods. Prog Brain Res 158: 109-125.

43. Mirnics K, Levitt P \& Lewis DA (2006): Critical appraisal of DNA microarrays in psychiatric genomics. Biol Psychiatry 60: 163-176.

44. Sequeira PA, Martin MV \& Vawter MP (2012): The first decade and beyond of transcriptional profiling in schizophrenia. Neurobiol Dis 45: 23-36.

45. Tsuang MT, Nossova N, Yager T, Tsuang MM, Guo SC, et al. (2005): Assessing the validity of blood-based gene expression profiles for the classification of schizophrenia and bipolar disorder: a preliminary report. Am J Med Genet B Neuropsychiatr Genet 133B: 1-5.

46. Takahashi M, Hayashi H, Watanabe Y, Sawamura K, Fukui N, et al. (2010): Diagnostic classification of schizophrenia by neural network analysis of blood-based gene expression signatures. Schizophr Res 119: 210-218.

47. Yao Y, Schroder J \& Karlsson H (2008): Verification of proposed peripheral biomarkers in mononuclear cells of individuals with schizophrenia. J Psychiatr Res 42: 639-643.

48. Glatt SJ, Stone WS, Nossova N, Liew CC, Seidman LJ \& Tsuang MT (2011): Similarities and 
differences in peripheral blood gene-expression signatures of individuals with schizophrenia and their first-degree biological relatives. Am J Med Genet B Neuropsychiatr Genet 156B: 869-887.

49. Vawter MP, Ferran E, Galke B, Cooper K, Bunney WE \& Byerley W (2004): Microarray screening of lymphocyte gene expression differences in a multiplex schizophrenia pedigree. Schizophr Res 67: 41-52.

50. Petryshen TL, Middleton FA, Kirby A, Aldinger KA, Purcell S, et al. (2005): Support for involvement of neuregulin 1 in schizophrenia pathophysiology. Mol Psychiatry 10: 366-374, 328.

51. Petryshen TL, Middleton FA, Tahl AR, Rockwell GN, Purcell S, et al. (2005): Genetic investigation of chromosome 5q GABAA receptor subunit genes in schizophrenia. Mol Psychiatry 10: 1074-1088, 1057.

52. Yang S, Van Dongen HP, Wang K, Berrettini W \& Bucan M (2009): Assessment of circadian function in fibroblasts of patients with bipolar disorder. Mol Psychiatry 14: 143-155.

53. Huang JT, Wang L, Prabakaran S, Wengenroth M, Lockstone HE, et al. (2008): Independent protein-profiling studies show a decrease in apolipoprotein A1 levels in schizophrenia CSF, brain and peripheral tissues. Mol Psychiatry 13: 1118-1128.

54. Herberth M, Koethe D, Levin Y, Schwarz E, Krzyszton ND, et al. (2011): Peripheral profiling analysis for bipolar disorder reveals markers associated with reduced cell survival. Proteomics 11: 94-105.

55. Levin Y, Wang L, Schwarz E, Koethe D, Leweke FM \& Bahn S (2010): Global proteomic profiling reveals altered proteomic signature in schizophrenia serum. Mol Psychiatry 15: 1088-1100.

56. Martins-de-Souza D, Guest PC, Vanattou-Saifoudine N, Harris LW \& Bahn S (2011): Proteomic technologies for biomarker studies in psychiatry: advances and needs. Int Rev Neurobiol 101: 65-94.

57. English JA, Pennington K, Dunn MJ \& Cotter DR (2011): The neuroproteomics of schizophrenia. Biol Psychiatry 69: 163-172.

58. Mangano RM \& Schwarcz R (1981): The human platelet as a model for the glutamatergic neuron: platelet uptake of L-glutamate. J Neurochem 36: 1067-1076.

59. Baier PC, Koch JM, Seeck-Hirschner M, Ohlmeyer K, Wilms S, et al. (2009): A flow-cytometric method to investigate glutamate-receptor-sensitivity in whole blood platelets - results from healthy controls and patients with schizophrenia. J Psychiatr Res 43: 585-591.

60. Pilowsky LS, Bressan RA, Stone JM, Erlandsson K, Mulligan RS, et al. (2006): First in vivo evidence of an NMDA receptor deficit in medication-free schizophrenic patients. Mol Psychiatry 11: 118-119.

61. Hayashi-Takagi A \& Sawa A (2010): Disturbed synaptic connectivity in schizophrenia: convergence of genetic risk factors during neurodevelopment. Brain Res Bull 83: 140-146.

62. Ryan MC, Collins P \& Thakore JH (2003): Impaired fasting glucose tolerance in first-episode, 
Hayashi-Takagi et al. 24

drug-naive patients with schizophrenia. Am J Psychiatry 160: 284-289.

63. Andreasen NC, Rezai K, Alliger R, Swayze VW, 2nd, Flaum M, et al. (1992): Hypofrontality in neuroleptic-naive patients and in patients with chronic schizophrenia. Assessment with xenon 133 single-photon emission computed tomography and the Tower of London. Arch Gen Psychiatry 49: 943-958.

64. Steen RG, Hamer RM \& Lieberman JA (2005): Measurement of brain metabolites by $1 \mathrm{H}$ magnetic resonance spectroscopy in patients with schizophrenia: a systematic review and meta-analysis. Neuropsychopharmacology 30: 1949-1962.

65. Prabakaran S, Swatton JE, Ryan MM, Huffaker SJ, Huang JT, et al. (2004): Mitochondrial dysfunction in schizophrenia: evidence for compromised brain metabolism and oxidative stress. Mol Psychiatry 9: 684-697, 643.

66. Scriver C, Beaudet A, Sly W, Valle D, Childs B, et al. (2000): The Metabolic and Molecular Bases of Inherited Disease. McGraw-Hill Professional.

67. Kaiya H, Nishida A, Imai A, Nakashima S \& Nozawa Y (1989): Accumulation of diacylgylcerol in platelet phosphoinositide turnover in schizophrenia: a biological marker of good prognosis? Biol Psychiatry 26: 669-676.

68. Yao J, Stanley JA, Reddy RD, Keshavan MS \& Pettegrew JW (2002): Correlations between peripheral polyunsaturated fatty acid content and in vivo membrane phospholipid metabolites. Biol Psychiatry 52: 823-830.

69. Schwarz E, Prabakaran S, Whitfield P, Major H, Leweke FM, et al. (2008): High throughput lipidomic profiling of schizophrenia and bipolar disorder brain tissue reveals alterations of free fatty acids, phosphatidylcholines, and ceramides. J Proteome Res 7: 4266-4277.

70. Freeman MP, Hibbeln JR, Wisner KL, Davis JM, Mischoulon D, et al. (2006): Omega-3 fatty acids: evidence basis for treatment and future research in psychiatry. J Clin Psychiatry 67: 1954-1967.

71. Kidd PM (2007): Omega-3 DHA and EPA for cognition, behavior, and mood: clinical findings and structural-functional synergies with cell membrane phospholipids. Altern Med Rev 12: 207-227.

72. Peet M, Horrobin DF \& Group EEMS (2002): A dose-ranging exploratory study of the effects of ethyl-eicosapentaenoate in patients with persistent schizophrenic symptoms. J Psychiatr Res 36: 7-18.

73. Katsel P, Davis KL, Li C, Tan W, Greenstein E, et al. (2008): Abnormal indices of cell cycle activity in schizophrenia and their potential association with oligodendrocytes. Neuropsychopharmacology 33: 2993-3009.

74. Shepherd RA, Bates PR \& McGrath JJ (1993): Cell cycle characteristics and schizophrenia. Biol Psychiatry 33: 60-61.

75. Jarskog LF, Selinger ES, Lieberman JA \& Gilmore JH (2004): Apoptotic proteins in the temporal cortex in schizophrenia: high $\mathrm{Bax} / \mathrm{Bcl}-2$ ratio without caspase-3 activation. Am J Psychiatry 
Hayashi-Takagi et al. 25

161: 109-115.

76. Allen NC, Bagade S, McQueen MB, Ioannidis JP, Kavvoura FK, et al. (2008): Systematic meta-analyses and field synopsis of genetic association studies in schizophrenia: the SzGene database. Nat Genet 40: 827-834.

77. Catts VS, Catts SV, O'Toole BI \& Frost AD (2008): Cancer incidence in patients with schizophrenia and their first-degree relatives - a meta-analysis. Acta Psychiatr Scand 117: 323-336.

78. Mukherjee S, Mahadik SP, Schnur DB, Laev H \& Reddy R (1994): Abnormal growth of cultured skin fibroblasts associated with poor premorbid history in schizophrenic patients. Schizophr Res 13: 233-237.

79. Terwisscha van Scheltinga AF, Bakker SC \& Kahn RS (2010): Fibroblast growth factors in schizophrenia. Schizophr Bull 36: 1157-1166.

80. Eaton WW, Byrne M, Ewald H, Mors O, Chen CY, et al. (2006): Association of schizophrenia and autoimmune diseases: linkage of Danish national registers. Am J Psychiatry 163: 521-528.

81. Schwab SG, Hallmayer J, Freimann J, Lerer B, Albus M, et al. (2002): Investigation of linkage and association/linkage disequilibrium of HLA A-, DQA1-, DQB1-, and DRB1-alleles in 69 sib-pair- and 89 trio-families with schizophrenia. Am J Med Genet 114: 315-320.

82. Drzyzga L, Obuchowicz E, Marcinowska A \& Herman ZS (2006): Cytokines in schizophrenia and the effects of antipsychotic drugs. Brain Behav Immun 20: 532-545.

83. Potvin S, Stip E, Sepehry AA, Gendron A, Bah R \& Kouassi E (2008): Inflammatory cytokine alterations in schizophrenia: a systematic quantitative review. Biol Psychiatry 63: 801-808.

84. Saijo K \& Glass CK (2011): Microglial cell origin and phenotypes in health and disease. Nat Rev Immunol 11: 775-787.

85. Schwarz E, Izmailov R, Spain M, Barnes A, Mapes JP, et al. (2010): Validation of a blood-based laboratory test to aid in the confirmation of a diagnosis of schizophrenia. Biomark Insights 5: 39-47.

86. Schwarz E, Guest PC, Steiner J, Bogerts B \& Bahn S (2012): Identification of blood-based molecular signatures for prediction of response and relapse in schizophrenia patients. Transl Psychiatry 2: e82. 
Hayashi-Takagi et al. 26

Table 1 Similarities and/or differences between peripheral sample and CNS samples

\begin{tabular}{|c|c|c|c|c|c|c|c|c|c|}
\hline \multirow[b]{2}{*}{ Disease } & \multicolumn{3}{|c|}{ Sampling } & \multirow{2}{*}{$\begin{array}{c}\text { Research } \\
\text { design } \\
\text { /focus } \\
\end{array}$} & \multirow{2}{*}{$\begin{array}{l}\text { Experimental } \\
\text { method }\end{array}$} & \multirow[b]{2}{*}{ Findings } & \multirow{2}{*}{\begin{tabular}{|c|} 
Similarities \\
between CNS and \\
periphery
\end{tabular}} & \multicolumn{2}{|c|}{ References } \\
\hline & Periphery & CNS & $\begin{array}{l}\text { From same } \\
\text { individuals }\end{array}$ & & & & & Year, Journal & PMID \\
\hline \multicolumn{10}{|c|}{ Genomics } \\
\hline BPD & LCLs & $\begin{array}{l}\text { Postmortem } \\
\text { brain } \\
\text { (DLPFC) }\end{array}$ & No & $\begin{array}{l}\text { An unbiased } \\
\text { genome-wide }\end{array}$ & DNA microarray & $\begin{array}{l}\text { Differential expressions of } \\
\text { PDLIM5 and HSPF1 both in } \\
\text { blood and brain of BPD. }\end{array}$ & \begin{tabular}{|l|} 
Two genes, out of 10 \\
genes identified in \\
postmortem, were \\
replicated in LCLs.
\end{tabular} & $\begin{array}{l}\text { 2004, Mol } \\
\text { Psychiatry }\end{array}$ & 14743183 \\
\hline SZ & Blood & $\begin{array}{l}\text { Postmortem } \\
\text { brain } \\
\text { (DLPFC) }\end{array}$ & No & $\begin{array}{l}\text { An unbiased } \\
\text { genome-wide }\end{array}$ & DNA microarray & $\begin{array}{l}\text { Up-regulation of SELENBP1 } \\
\text { both in blood and brain of SZ. }\end{array}$ & \begin{tabular}{|l|} 
Six genes, out of 177 \\
genes identified in \\
postmortem, were \\
replicated in blood.
\end{tabular} & $\begin{array}{l}\text { 2005, Proc Natl } \\
\text { Acad Sci U S A }\end{array}$ & 16223876 \\
\hline Control & Blood & $\begin{array}{l}\text { Postmortem } \\
\text { brain } \\
\text { (Multiple } \\
\text { regions) }\end{array}$ & No & $\begin{array}{l}\text { An unbiased } \\
\text { genome-wide }\end{array}$ & DNA microarray & $\begin{array}{l}\text { (1) Similarity of some } \\
\text { signaling between blood/PFC. } \\
\text { (2) Half of SZ genes expressed } \\
\text { both in blood/PFC. }\end{array}$ & $\begin{array}{l}\text { Some signaling were } \\
\text { similar. }\end{array}$ & $\begin{array}{l}\text { 2006, Am J Med } \\
\text { Genet B } \\
\text { Neuropsychiatr } \\
\text { Genet }\end{array}$ & 16526044 \\
\hline SZ/Control & Lymphocyte & $\begin{array}{l}\text { Postmortem } \\
\text { brain (PFC) }\end{array}$ & No & HTR2A & RT-PCR & $\begin{array}{l}\text { Disease associated SNP 102C } \\
\text { is expressed lower than 102T } \\
\text { in brains. }\end{array}$ & \begin{tabular}{|l|} 
Lymphocyte: \\
monoallelic, Brain: \\
biallelic expression \\
\end{tabular} & $\begin{array}{l}\text { 2006, Biol } \\
\text { Psychiatry }\end{array}$ & 17069769 \\
\hline Control & Blood & $\begin{array}{l}\text { Meta-analysis } \\
\text { data }\end{array}$ & No & $\begin{array}{l}\text { An unbiased } \\
\text { genome-wide }\end{array}$ & DNA microarray & $\begin{array}{l}\text { Weak correlations between } \\
\text { mean expression between brain } \\
\text { and blood. }\end{array}$ & $\begin{array}{l}\text { Only some signaling } \\
\text { were similar. }\end{array}$ & \begin{tabular}{|l} 
2010, BMC \\
Genomics
\end{tabular} & 20961428 \\
\hline Control & $\begin{array}{l}\text { Postmortem } \\
\text { blood }\end{array}$ & $\begin{array}{l}\text { Postmortem } \\
\text { brain } \\
\text { (Cerebellum) }\end{array}$ & Yes & $\begin{array}{l}\text { An unbiased } \\
\text { genome-wide }\end{array}$ & DNA microarray & $\begin{array}{l}22 \% \text { of total transcriptome } \\
\text { expressed in both cerebellum } \\
\text { and blood with high correlation } \\
(\gamma=0.98) \text {. }\end{array}$ & $\begin{array}{l}20 \% \text { genes were } \\
\text { expressed at similar } \\
\text { level between blood } \\
\text { and brain. }\end{array}$ & \begin{tabular}{|l|} 
2010, Am J Med \\
Genet B \\
Neuropsychiatr \\
Genet \\
\end{tabular} & 20127885 \\
\hline SZ & \begin{tabular}{|l} 
Blood \\
(Discordant \\
MZ twins) \\
\end{tabular} & $\begin{array}{l}\text { Postmortem } \\
\text { brain }\end{array}$ & No & $\begin{array}{l}\text { An unbiased } \\
\text { methylome-wide }\end{array}$ & $\begin{array}{l}\text { Methylation } \\
\text { microarray }\end{array}$ & $\begin{array}{l}\text { Hypomethylation of } \\
\text { ST6GALNAC1 both in blood } \\
\text { and brain of SZ }\end{array}$ & $\begin{array}{l}\text { Brain DNA } \\
\text { methylation were } \\
\text { higher }(\sim 85 \%) \text { than } \\
\text { the blood }(\sim 40 \%) . \\
\end{array}$ & $\begin{array}{l}\text { 2011, Hum Mol } \\
\text { Genet }\end{array}$ & 21908516 \\
\hline BPD & LCLs & $\begin{array}{l}\begin{array}{l}\text { Postmortem } \\
\text { brain (PFC) }\end{array} \\
\end{array}$ & No & \begin{tabular}{|l|} 
An unbiased \\
promoter-wide \\
\end{tabular} & $\begin{array}{l}\text { Promoter tiling array } \\
\text { and pyrosequencing }\end{array}$ & $\begin{array}{l}\text { Hypermethylation of SLC6A4 } \\
\text { both in blood and brain of BPD }\end{array}$ & & \begin{tabular}{|l|}
$\begin{array}{l}\text { 2011, Transl } \\
\text { Psychiatry }\end{array}$ \\
\end{tabular} & 22832526 \\
\hline BPD & $\begin{array}{l}\text { Bloods, and } \\
\text { Sperm }\end{array}$ & $\begin{array}{l}\text { Postmortem } \\
\text { brain }\end{array}$ & No & HCG9 & Bisulfite sequence & $\begin{array}{l}\text { Hypomethylation of HLA } \\
\text { group } 9 \text { gene (HCG9) in all } \\
\text { tissues of BPD }\end{array}$ & $\begin{array}{l}\text { HCG9 methylation } \\
\text { profiles were similar } \\
\text { across tissues }\end{array}$ & $\begin{array}{l}\text { 2012, Mol } \\
\text { Psychiatry }\end{array}$ & 21647149 \\
\hline Control & $\begin{array}{l}\text { Blood (Prior } \\
\text { to death) }\end{array}$ & $\begin{array}{l}\text { Postmortem } \\
\text { brain } \\
\text { (Multiple } \\
\text { regions) }\end{array}$ & Yes & $\begin{array}{l}\text { An unbiased } \\
\text { methylome-wide }\end{array}$ & $\begin{array}{l}\text { Methylated DNA } \\
\text { immunoprecipitation }\end{array}$ & $\begin{array}{l}\text { Highly distinct patterns of } \\
\text { DNA methylation between } \\
\text { CNS and blood }\end{array}$ & \begin{tabular}{|l|} 
Methylation was \\
generally tissue- \\
specific, while that of \\
CpG-rich promoter is \\
largely similar. \\
\end{tabular} & 2012, Genome Biol & 22703893 \\
\hline SZ/Control & Blood & $\begin{array}{l}\text { Postmortem } \\
\text { brain }\end{array}$ & No & $\begin{array}{l}\text { An unbiased } \\
\text { methylome-wide }\end{array}$ & $\begin{array}{l}\text { Methylation } \\
\text { microarray }\end{array}$ & $\begin{array}{l}\text { Methylation levels was less } \\
\text { variable than gene expression. }\end{array}$ & $\begin{array}{l}\text { Moderate similarity } \\
\text { of age-related CpG } \\
\text { methylation }(\gamma= \\
0.33) \text {. } \\
\end{array}$ & 2012, Genome Biol & 23034122 \\
\hline
\end{tabular}

\section{Proteomics/Metabolics}

\begin{tabular}{|c|c|c|c|c|c|c|c|c|c|}
\hline $\begin{array}{l}\text { Control } \\
\text { (SIDS) }\end{array}$ & Blood & Cortex, retina & Yes & $\begin{array}{l}\text { Fatty acid } \\
\text { composition }\end{array}$ & Gas chromatography & $\begin{array}{l}\text { Breast-fed infants had a higher } \\
\text { DHA\% both in brain and RBC. }\end{array}$ & $\begin{array}{l}\text { Similar DHA\% } \\
\text { between brain/RBC } \\
(\gamma=0.33) .\end{array}$ & $\begin{array}{l}\text { 1994, Am J Clin } \\
\text { Nutr }\end{array}$ & 7913291 \\
\hline $\begin{array}{l}\text { SZ/BPD/ } \\
\text { Control }\end{array}$ & RBC & $\begin{array}{l}\text { Postmortem } \\
\text { brain } \\
\text { (DLPFC) }\end{array}$ & No & $\begin{array}{l}\text { Lipid } \\
\text { composition }\end{array}$ & Mass spectrometry & $\begin{array}{l}\text { Alterations in the free fatty } \\
\text { acids and ceramide both in } \\
\text { blood and brain of SZ and } \\
\text { BPD group. }\end{array}$ & $\begin{array}{l}\text { Closely correlated, } \\
\text { but quantitatively } \\
\text { different between } \\
\text { brain and RBC. }\end{array}$ & $\begin{array}{l}\text { 2008, J Proteome } \\
\text { Res }\end{array}$ & 18778095 \\
\hline SZ & $\begin{array}{l}\text { RBC, } \\
\text { Serum, and } \\
\text { Liver }\end{array}$ & $\begin{array}{l}\text { Postmortem } \\
\text { brain, CSF }\end{array}$ & $\begin{array}{l}\text { Partially } \\
\text { Yes }\end{array}$ & $\begin{array}{l}\text { Proteomic } \\
\text { profiling }\end{array}$ & $\begin{array}{l}\text { Mass spectroscopy } \\
\text { and 2D-DIGE }\end{array}$ & $\begin{array}{l}\text { Down-regulation of ApoA1 in } \\
\text { all } 5 \text { tissues of SZ. }\end{array}$ & $\begin{array}{l}\text { No correlation of } \\
\text { CSF and serum } \\
\text { apoA1 levels from } \\
\text { the same subjects. } \\
\end{array}$ & $\begin{array}{l}\text { 2008, Mol } \\
\text { Psychiatry }\end{array}$ & 17938634 \\
\hline $\mathrm{SZ}$ & Serum & $\begin{array}{l}\text { Postmortem } \\
\text { brain (BA10) }\end{array}$ & No & $\begin{array}{l}\text { Proteomic/ } \\
\text { Metabolic } \\
\text { profiling }\end{array}$ & $\begin{array}{l}\text { Multiplex } \\
\text { immunoassay panel } \\
\text { (187 molecules) }\end{array}$ & $\begin{array}{l}21 \text { analytes was altered in SZ } \\
\text { postmortem brain }\end{array}$ & $\begin{array}{l}5 \text { analytes showed } \\
\text { same directional } \\
\text { change both tissue. }\end{array}$ & 2012, PLoS One & 23118852 \\
\hline
\end{tabular}

\section{Functional cellular assay}

\begin{tabular}{|c|c|c|c|c|c|c|c|c|c|}
\hline $\mathrm{SZ}$ & $\begin{array}{l}\text { Skin } \\
\text { fibroblast }\end{array}$ & $\begin{array}{l}\text { Multiple } \\
\text { regions }\end{array}$ & Yes & $\begin{array}{l}\text { Comparison of } \\
\text { tyrosine kinetics }\end{array}$ & $\begin{array}{l}\text { Uptake of tyrosine } \\
\text { (Fibroblast). } \\
\text { Tyrosine transport } \\
\text { across BBB (PET). }\end{array}$ & $\begin{array}{l}\text { Utilization of tyrosine was } \\
\text { lower in the SZ (PET), and } \\
\text { tyrosine transport was } \\
\text { decreased in the fibroblast. }\end{array}$ & $\begin{array}{l}\text { Similar tyrosine } \\
\text { kinetics between } \\
\text { tissues }\end{array}$ & \begin{tabular}{|l} 
1991, J Nucl Med; \\
1994, Schizophr Res
\end{tabular} & $\begin{array}{l}1941137 \\
7841139\end{array}$ \\
\hline MDD & Platelet & CSF & Yes & $\begin{array}{l}\text { Comparison of } \\
\text { 5-HT indexes }\end{array}$ & \begin{tabular}{|l} 
5-HT index \\
(Platelet), \\
5-HT (CSF)
\end{tabular} & $\begin{array}{l}\text { No correlation between platelet } \\
\text { and CSF for 5-HT indexes }\end{array}$ & $\begin{array}{l}\text { No support for the } \\
\text { use of platelet for } \\
\text { CFS 5-HT } \\
\text { monitoring } \\
\end{array}$ & $\begin{array}{l}\text { 1992, Arch Gen } \\
\text { Psychiatry }\end{array}$ & 1376106 \\
\hline $\begin{array}{l}\text { SZ (first } \\
\text { episode, } \\
\text { drug naïve) }\end{array}$ & RBC & Living brain & Yes & $\begin{array}{l}\text { Comparison of } \\
\text { lipid metabolism }\end{array}$ & $\begin{array}{l}\text { Fatty acids (RBC) } \\
\text { 31P-MRS (Brain) }\end{array}$ & $\begin{array}{l}\text { A parallel decrease in RBC } \\
\text { phospholipid fatty acids and } \\
\text { phospholipid metabolism in the } \\
\text { PFC of SZ individuals. }\end{array}$ & $\begin{array}{l}\text { Similarity between } \\
\text { RBC and PFC lipid } \\
\text { metabolism }(\gamma= \\
0.56) . \\
\end{array}$ & \begin{tabular}{|l} 
2002, Biol \\
Psychiatry
\end{tabular} & 12372654 \\
\hline Control & Plasma & mPFC & Yes & $\begin{array}{l}\text { Monitoring the } \\
\text { brain Glu by } \\
\text { plasma }\end{array}$ & $\begin{array}{l}\text { HPLC (Plasma) } \\
\text { 1H-MRS (Brain) }\end{array}$ & $\begin{array}{l}\text { No correlation between plasma } \\
\text { and mPFC for Glu and Glx } \\
\text { (Glu + Gln) concentration }\end{array}$ & $\begin{array}{l}\text { No support for the } \\
\text { use of blood for CNS } \\
\text { Glu monitoring }\end{array}$ & $\begin{array}{l}\text { 2006, J Psychiatry } \\
\text { Neurosci }\end{array}$ & 17136218 \\
\hline SZ & Platelet & Living brain & Yes & $\begin{array}{l}\text { Platelet as a } \\
\text { predictor of } \\
\text { CNS function }\end{array}$ & $\begin{array}{l}\text { Mitochondrial } \\
\text { complex I (Platelet) } \\
\text { FDG-PET (Brain) }\end{array}$ & $\begin{array}{l}\text { Complex I activity in platelet } \\
\text { was correlated with PANSS } \\
\text { and cerebral glucose } \\
\text { metabolism }\end{array}$ & $\begin{array}{l}\text { Similarity between } \\
\text { peripheral and } \\
\text { cerebral energy } \\
\text { metabolism } \\
\end{array}$ & $\begin{array}{l}\text { 2007, Prog } \\
\text { Neuropsycho Biol } \\
\text { Psychiatry }\end{array}$ & 17329000 \\
\hline MDD/BPD & Plasma & Living brain & Yes & $\begin{array}{l}\text { Monitoring the } \\
\text { brain PUFAs } \\
\text { level by plasma }\end{array}$ & $\begin{array}{l}\text { PUFA (Plasma) } \\
\text { FDG-PET (Brain) }\end{array}$ & $\begin{array}{l}\text { Temporoparietal glucose usage } \\
\text { correlated positively with both } \\
\text { DHA\% and AA\%. }\end{array}$ & $\begin{array}{l}\text { Similar PUFA ratio } \\
\text { between plasma and } \\
\text { cortex }(\gamma=0.77) \text {. }\end{array}$ & \begin{tabular}{|l|}
2009, \\
Prostaglandins \\
Leukot Essent Fatty \\
Acids
\end{tabular} & 19128951 \\
\hline
\end{tabular}

Abbreviation: 2D-DIGE: two-dimensional difference gel electrophoresis, CSF: cerebrospinal fluid, BBB: blood-brain barrier, Glu: glutamate, 
Hayashi-Takagi et al. 27

Gln: glutamine, LCLs: lymphoblastoid cell lines, MZ: monozygotic, PBMC: peripheral blood mononuclear cell, PUFA: polyunsaturated fatty acids, SIDS: sudden infant death syndrome. 